\title{
Trosopplæring for de aller minste
}

\author{
Praksiserfaringer rundt babyteater $i$ kirken
}

\begin{abstract}
Av Elin Oveland
Plan for trosopploering sier at alle dopte 0-18 år skal få tilbud om en systematisk og helhetlig trosopplaring. Hvordan skal vi fä til det for de aller minste barna? De som ikke enda har ord for å si hva de trenger, eller gi tilbakemelding på hva de tenker? Når vi ikke vet hva de forstår av det vi sier til dem? Kan man undervise disse barna? Kan de laere noe? Og hvordan kan de i så fall erfare og tilegne seg trosopplaring på egne premisser? Dette er noen av spørsmålsstillingene som ligger bak vår praksis med babyteater $i$ Asker prosti. I møte med de aller minste var vi nodt til å tenke nytt om laering og formidling, samt se helhetlig trosopplaring fra et nytt perspektiv.
\end{abstract}

\section{Elin Oveland, født 1980, teaterpedagog/ produsent for De Minstes Teater, ungdomsarbeider og barne-og ungdomskonsulent, Kristiansand, elin.oveland@icloud.com}

\section{BAKGRUNN}

Da jeg var nyutdannet teaterpedagog og menighetspedagog startet jeg å jobbe som trosopplærer i en menighet i Asker prosti. Sammen med kateketen i menigheten hadde vi ansvar for å både utforme en trosopplæringsplan, og å gjennomføre tiltakene. Fra fireårsfasen og oppover hadde vi mange tiltak i planen som vi også klarte å gjennomføre. For den yngste målgruppen opplevde vi derimot at vi strevde med å finne både form og innhold som passet. Vi så at vi var gode på å legge til rette for de voksne ledsagerne, vi var gode på sang, og på det diakonale. Men når det kom til fortellingene og annet trosinnhold var vi rådville.

Arbeidet med babysang ble et sted å starte. Her fikk jeg mulighet til å bli kjent med både babyer og ledsagere, og jeg fikk eksperimentere med ulike teknikker etter hvert som gruppene og jeg ble kjent. Jeg eksperimenterte med instrument som lager lyder og stemninger, med ulike gjenstander, med bevegelser rundt $\mathrm{i}$ kirkerommet og med bruk av ord og bibelvers. Jeg var opptatt av at det jeg tilbudte babyene og de foresatte kunne ha en dypere mening. Vi flyttet sangstunden inn $\mathrm{i}$ kirkerommet, og jeg sydde et teppe som målte $5 \times 2 \mathrm{~m}$ hvor jeg applikerte dåpslyset. Her fikk alle plass på ett og samme teppe, og det ble lagt foran alteret. Babyene skulle også få være i kirkerommet; høre, se, kjenne og erfare ordene og handlingene og gjenstandene som tilhører vårt felles, kristne kirkerom.

Etter hvert fikk jeg barn selv. I møte med henne som baby oppdaget jeg at mye av vår kommunikasjon gikk ut på å peke på, undersøke og gjenta navn på ting. Hun gjentok og gjentok «Oi! Se!» mens hun pekte, så på meg og smilte. Denne erfaringen tok jeg med meg inn i møte med babysanggruppene jeg hadde. Jeg

Prismet - IKO-Forlaget 2021

Tilgjengelig på https://journals.uio.no/index.php/prismet Publisert under CC BY-NC 4.0.

Årgang 72, hefte 1, s. 57-65

ISSN: 0032-8847, ISSN online:2535-311x 
begynte å peke og gjenta «Oi! Se!» mens jeg smilte og så overrasket/ spent ut.

Da barnet mitt var blitt ett år tok jeg henne med på en babyteaterforstilling på det lokale kulturhuset. Møtet med det vi opplevde der ble en øyeåpner for meg, og jeg sa til meg selv: dette kan vi gjøre også i kirken!

Inspirert av babyteaterforestillingen på kulturhuset gikk jeg i gang med å lære mer om hva babyteater er. Jeg allierte meg med de i prostiet som muligens har mest kunst $i$ utdanningsbakgrunnene sine og som er opptatt av stemning og musikkens virkning: kirkemusikerne. De støttet meg i å teste ut noe. Jeg fikk også med meg to andre menighetspedagoger i prostiet å være kreativ med. Slik startet vi arbeidet med å utvikle babyteater i trosopplæringen, med babysanggruppene som et fortsatt verdifullt testpublikum. Babyene vi da viste for var fra fire til 13 måneder, flest rundt syv-åtte. Etter hvert prøvde vi ut flere aldersgrupper og barnehagegrupper med sammensatte aldersgrupper. Vi fikk raskt gode erfaringer og begynte å legge inn de ulike forestillingene inn i trosopplæringsplanene våre; i ettårsfasen, treårsfasen og femårsfasen.

\section{B ABYTEATER}

Babyteater er et relativt nytt fenomen, og det er kun de siste 30 årene fenomenet er blitt mer allment, og anerkjent som teaterform (Hovik 2014: 27). Gerd Taube (i Schneider 2009) skriver at sjangeren babyteater skiller seg fra klassiske teaterforestillinger ved at scene og sal ikke er definert og adskilt på den klassiske måten. Forestillingene er interaktive og barnas reaksjoner og handlinger er med og preger selve forestillingen. Innholdet $\mathrm{i}$ forestillingene er også preget av en direkte eller indirekte samhandling mellom babyer og skuespillere. Babyene skal ikke identifisere seg med skuespillerne, i stedet er målet at man skal undersøke, undre seg over, oppdage og gjenta ting sammen. Skuespillernes bevegelser er ofte dansepregede, og musikk er en essensiell del av en forestilling for babyer. Musikken fungerer både som stemningsskaper, og som en slags kommentar eller utfyllende karakteristikk til en gjenstand. (Det kan for eksempel si «pling» når man tar på noe, eller en lyd kan kalle på oppmerksomheten rundt en gjenstand.) Scenografi og kostymer i forestillingene er gjerne preget av sterke farger og ulike former og kontraster.

\section{VARE FORESTILLINGER}

På fem år lagde vi fem forestillinger. De har alle ulik tematikk og ulikt preg. Noen har vært korte, andre lange. Noen har hatt én skuespiller, andre har hatt tre. Vi har laget forestillinger uten ord, andre med ord. Vi har brukt musikere og vi har spilt inn et eget lydbånd. Felles for forestillingene er langsomheten, undringen, smilene, pekingen, det meditative, og glitrende rekvisitter. Alle forestillingene har også hatt samme ramme ved at de starter og slutter ved hjelp av tre «pling» i finger- 
cymbaler. Tre slag for treenigheten, kirkeklokkenes ringing og for teaterhusenes tradisjon om tre slag før en forestilling. Babyteatersjangeren tar jo også inn over seg på en særlig måte publikum, og hver visning har latt seg prege av hvem som har vært til stede. Dersom vi har spilt for større barn som fem- og seksåringer, har vi endret kroppsspråket og langsomheten noe. Dersom vi har spilt for veldig små babyer har vi vært ekstra varsomme i samhandlingen med dem. Når vi har spilt i kirkerom for store publikum eller i gudstjenestesammenheng har vi tydeliggjort kroppsspråk og bevegelser, og tatt særlig hensyn til behovet for synlighet også for dem bakover i benkeradene. Alle kostymer og rekvisitter ble laget av meg og av oss eller funnet på lokale gjenbruksbutikker.

Teologisk har vi valgt å aktivt unngå kjønnsbetegnelsen på Gud der hvor Gud har vært representert ved en skuespiller. Når Guds navn har vært nevnt, har vi dermed sagt kun Gud og ikke «han» eller «hun». Truppen har også, mer eller mindre tilfeldig, alltid bestått av kvinner. Dermed har vi valgt å bruke kjoler som kostymer, og slik spille på det feminine uttrykket ved Gud. Dersom forestillingene skal spilles av menn, kan de gjerne bruke en fargerik jakke og bukser. Vi har valgt å la Gud gjenspeiles i skuespillernes person, og ikke på tvers av.

$$
\text { 2014: «Oii, Se!» }
$$

16 min, 2 «skuespillere» og 1 musiker med soundboard og tromme. Noen ord: «oii» og «se», «didi», «dodo» og «97, 98, 99, borte!?»

Denne forestillingen ble vist for babysanggrupper i prostiet, og vi spilte på gjenkjennelse fra babysangprogrammene våre. Flere av sangene ble brukt, samt elementene med et blått tøystykke i chiffon som symboliserer havet, rasleegg, og såpebobler. Skuespillerne spilte «småbarn», med klovneriske tendenser, og undersøkte en rød koffert med tre bibelske temaer/fortellinger. I kofferten fant vi en hjertepute, en stor skinnfell og et blått tøystykke. Hjerteputen skulle visualisere Guds kjærlighet, den store skinnfellen ble brukt for å vise historien om den bortkomne sauen. Det blå tøystykket sammen med sangen «Her sitter vi og ror» visualiserte historien om Jesus som stiller stormen. Underveis i arbeidet med forestillingen stilte vi oss spørsmålet om hvorvidt voksne egentlig kunne kjenne igjen fortellingene, samt om de forstod hvilke bibelfortellinger vi henviste til. Som et resultat av det delte vi et lite ark før forestillingen til de voksne hvor vi skrev litt om forestillingens innhold.

«Oii, Se!» fikk enormt positiv respons fra de voksne, og vi så at babyene var «med på leken». Dette gav mersmak og vi gikk snart i gang med flere forestillinger.

2015: «Lille frø»

7,5 min, 2 skuespillere og 1 musiker. Ingen ord.

Bakgrunnen for denne forestillingen var at vi ble spurt om vi kunne lage en preken 
til en stabbemesse rundt lignelsen om sennepsfrøet. I «Lille frø» var vi to skuespillere kledd ut som gartnere i seleshorts, utstyrt med vannkanner. Som en effekt sydde jeg et to meter høyt/ langt tre i stoff som vi trakk ut av en gullstoffpose (frøet) og hang opp i ei lysekrone som kunne senkes og heves. I noen lommer foran på selebuksene hadde vi noen «reir» i gullstoff kjøpt på en indisk stoffbutikk. Vi lagde seks fugler av papp og farget bomull. Vi la dem i en kurv ved alteret og hentet dem frem derfra mens vi lot en og en «fly» $\mathrm{i}$ hånden rundt til publikum. Til slutt festet vi dem i reirene ved hjelp av trykknapper. Musikken var preget av å lydsette det som skjedde; regnstaven rislet når gartnerne vannet frøet, en marakas markerte en lyd for frøets vokseperiode, og til slutt når treet vokste opp spilte musikeren meditativ instrumental på piano. Når fuglene ble løftet frem og de «fløy» rundt spilte musikeren av fuglelyder og synthesizer fra Youtube. Alle skuespillernes bevegelser var sakte og koordinerte oss imellom, og vi holdt stadig hånden foran munnen med et overasket ansiktsuttrykk ut mot publikum.

$$
\text { 2016: «Oi, se! Dåpen!» }
$$

16 min, 3 skuespillere og 1 forteller som også styrer musikk/ rytmeinstrument.

2016 var et år med stort fokus i prostiet på dåp, og da lagde vi en forestilling til bruk i spesielle dåpsgudstjenester. Den lille «truppen» fikk også to kollegaer til på laget, og vi representerte til sammen fire av fem menigheter i prostiet. I denne forestillingen tok vi utgangspunkt i teksten om dåpen slik vi finner den i Gudsrikeleikens tekster. Denne, og andre tekster i Gudsrikeleiken har samme undring og stemning som vi er ute etter i babyteater. Skuespillerne representerte de tre enhetene i treenigheten med hvite kjoler, ikledd hvert sitt treenighetssymbol. Vi undersøkte tre elementer i sammenheng med dåpen; en bærbar døpefont med glitrende blå stoffremser, kristuslyset og en fyrstikkeske, bibelen og tre glitrende duer. På slutten av hver utforskingsseksjon sa fortelleren noe som knyttet gjenstandene til dåpen og den store kristne fortellingen. Musikken i dette stykket er ulike rytmeinstrument som setter stemning; rasleegg, regnstav og fuglekvitter. Det brukes også en instrumental versjon av «Tenn lys». Denne forestillingen har vi brukt som utgangspunkt for ettårsfasen, hvor vi har invitert alle som ble døpt for ett år siden. Vi har vist forestillingen og delt ut en dåpsdue som har hengt $\mathrm{i}$ kirkerommet siden dagen de ble døpt. Duen er laget i samarbeid med en lokal keramiker. Forestillingen er senere modifisert slik at den kan spilles med én skuespiller og et lydbånd.

\section{7: «Oi, Se! Gud skaper!» 30 min, 1 skuespiller, 1 forteller og 1 musiker.}

Så ville vi prøve oss på en lengre forestilling, og noe vi kunne bruke i møte med barnehager. Vi fant en ny fortelling fra Gudsrikeleiken, og brukte den som utgangspunkt for en forestilling hvor skapelsens sju dager blir oppdaget og undersøkt ved 
hjelp av sju ulike esker med ulikt innhold. Her bruker vi flere instrument enn vi har gjort før i tillegg til rasleegg, regnstav og marakas. Vi brukte kalimba gjennomgående, samt englespill, en stor cymbal og en spilledåse. Vi gjenbrukte treet fra forestillingen «Lille frø», og havet fra både «Oi! Se! Dåpen!» og «oii! Se!». Vi la også inn et humoristisk innslag for de voksne: på den syvende dagen når Gud hviler, legger fortelleren fra seg den store boka, heller rykende kaffe i en kopp og slurper den høylytt i seg. Vi viste forestillingen først for et par barnehager, deretter babysanggrupper, og så la vi den inn i 3-årsfasene våre. I sammenheng med tiltaket for treåringene delte vi ut en søndagsskolepose i etterkant av forestillingen, hvor barna fikk ting de kunne bruke i en interaktiv vandring i kirkerommet rundt de sju ulike eskene/ dagene. Denne forestillingen har vi senere spilt inn et lydbånd til, og forkortet den ned til halve tiden til bruk i gudstjenester (kun ved å la skuespilleren spille mindre langsomt).

2018: «Oi, se! Jula varer helt til påske» 16 min, 3 skuespillere og 1 forteller som håndterer musikk/ instrumenter.

Etter noen års erfaring med de aller minste begynte vi å se på om vi kunne lage noe som passet for litt større barn og som kunne vises i tiden før påske. Vi ville gjøre noe som viste litt av Den store fortellingen; sammenhengen mellom Jesu fødsel i jula, underfortellingene vi forteller om ham, samt påskens historier. Vi ville også bruke og forklare noen av de ulike artefaktene som florerer i høytidene, men som barna ikke nødvendigvis skjønner den kristne meningen med: gaver, juletre, kalender, påskeegg, påskeliljer, kors, osv. Igjen så vi til Gudsrikeleikens tekster. Vi brukte de som utgangspunkt for forestillingen. Vi malte 11 pappesker grønne og stablet dem som et juletre. Fem av eskene kan tas ut og åpnes, og ved hjelp av dem gjenfortalte vi Jesu fødsel, Jesus velsigner barna, Jesus stiller stormen, Jesus helbreder den blinde mannen og påskens forløp fra palmesøndag til påskemorgen. De åpne kassene fungerer til slutt som utstillingsvindu for historiene og danner sammen et kors midt på pappesketreet. I denne forestillingen bruker vi mer instrumentalmusikk enn tidligere. Hver gang en eske åpnes er det som om det også kommer et musikkstykke eller en instrumental salme ut. En erfaren lytter gjenkjenner «Fra krybben til korset», «Milde Jesus», og «Påskemorgen slukker sorgen». Før forestillingen serverte vi oppspart julebrus. Etter forestillingen fikk barna dra på påskeeggjakt rundt kirken. Til denne forestillingen og tiltaket fikk vi aller størst oppmøte. Også denne forestillingen er tilrettelagt for kun én skuespiller, og også for å kunne brukes i forbindelse med julen.

\section{VÅR ERFARINGER}

Når man skal formidle og spille teater for så små barn er det ikke de muntlige tilbakemeldingene vi kan se etter. I stedet har vi merket oss hvordan barna på 
ulike måter responderer på forestillingene. Det første vi har erfart er at dette treffer disse minste barna. Noen sitter helt stille og følger oss med øynene under hele forestillingen. Noen krabber bort oss skuespillerne og tar tak i noen av artefaktene våre. Noen blir mer opptatt av gjenstandene og hverandre enn av hva vi skuespillere gjør. Vi ser at barna samhandler, enten om tingene, eller med blikk og lyder, eller med kroppene sine. Vi ser også at de voksne foresatte er viktige for barnas opplevelser; noen veileder barna ved hjelp av å peke, smile og si «se», andre ved å begrense barnas bevegelsesmulighet. Ofte ser vi at de voksne henter barna raskt tilbake dersom de krabbet ut over det som var definert som "publikumsteppet» og over på sceneområdet. Vi ser at babyene responderer på selve kirkerommet og ser seg mye og ofte rundt i starten. Mange tester også å lage lyder i det store rommet. Vi ser at babyene ikke «skjønner» når forestillingen starter og slutter, og de går ofte ut og inn av fokuset i forhold til det vi skuespillerne holder på med. Vi ser blant annet derfor at musikk og lyder spiller en viktig faktor for å beholde barnas konsentrasjon rundt forestillingen, eller «hente dem inn igjen». Bruken av rasleegg fungerer godt til det. Vi ser også at vi kan bruke ord i forestillingene, og vi tror at de fungerer som et slags lydbilde for barna og som en slags kommentar eller forklaring for de voksne.

I etterkant av forestillingene har vi fått mange positive tilbakemeldinger fra de voksne. Mange er overveldet og rørt over eget barns evne til konsentrasjon og positive respons og sier at barnet aldri har oppført seg slik som under forestillingen.

I møte med tilrettelegging av disse forestillingene for gudstjenestebruk har vi også erfart at voksne og eldre mennesker har kommet til oss og uttrykt at dette ikke kun var en opplevelse for barna, men også for dem. De har særlig pekt på det meditative uttrykket, på langsomheten og de utvalgte ordene. Vi tror at denne effekten kommer av kunstens - scenekunstens og musikkens egne evne til å nå oss uavhengig av alder og kognitive evner.

\section{UTFORDRINGER OG LØSNINGER Oppslutning}

Den største utfordringen for oss er oppmøte. Babyteater trekker ikke flere deltakere enn andre tiltak i kirken og små barn og barnefamilier kan være en utfordrende gruppe å legge til rette for med tanke på ulikheter i når barna sover, spiser, og rutinene til andre barn i familien. Det kan også ha noe å si hvilken kirke forestillingen vises $i$. At vi er flere kirker $i$ et prosti som samarbeider gjør oss fleksible, og vi har mulighet for å invitere til flere forestillinger og på flere steder i kommunen. De senere årene har vi jobbet aktivt med PR, og opparbeiding av omdømme. Vi har gitt teatertruppen et navn; De Minstes Teater. Vi har fătt en logo og vi er til stede på sosiale medier. Vi har også holdt kurs på IKO og lært bort forestillingene, 
og slik bidratt til at det jobbes med babyteater i flere kirker andre steder i landet. Forhåpentligvis vil alle disse faktorene være med å bidra til at flere får øynene opp for dette som et aktuelt tiltak å ta med babyene sine på.

\section{Storre søsken}

I noen tilfeller kommer det også større søsken som publikummere på forestillingene. Vi har ofte erfart at de kan ta fokuset fra de aller minste. Ofte fordi de er fysisk større og fordi de «tar plass» gjennom bevegelser og ord. I utgangspunktet er vi ikke negative til et publikum med ulik aldersspredning, men vi har merket oss at dersom vi ønsker å invitere spesielt babyene eller de minste barna, er det lurt å bare ha dem og deres foresatte som publikum.

\section{Storrelsen på publikum}

Når man viser en forestilling for de aller minste er det en fordel at det ikke er for mange publikummere til stede om gangen. Det kan føre til unødig og mye forstyrrelser. 20 babyer/ småbarn pluss ledsagere er ofte maksantall vi har satt. Det betyr at vi dermed må ha flere forestillinger dersom vi skal nå store kull. Vi har også spilt for større publikum, opp til godt over 100. Da har vi erfart at det kan være en fordel å anbefale de minste å sitte fremst, samt at lydanlegget bør kunne gi høy nok lyd slik at forestillingen preger rommet mer enn det publikummet kan gjøre.

\section{Sted og Tid}

Vi erfarte at det er utrolig viktig med den fysiske tilretteleggingen av kirkerommet for babyene. Det må være ok å kunne sette fra seg vogner. Rommet må være oppvarmet. Det må være et mykt og innbydende teppe babyene kan bevege seg trygt på. Dersom man kjenner gruppen man inviterer, kan man høre med dem for å få best mulig tidspunkt for forestillingen. Dersom man inviterer barn som er så store at de har begynt i barnehagen, kan det i tillegg være lurt å bruke en helg fremfor en ettermiddag.

\section{De voksne ledsagerne:}

Som nevnt er de voksne en viktig brikke i babyenes opplevelse av en babyteaterforestilling. Det er utrolig viktig at de blir informert og trygget på det som skal skje, og trygget på at dette er en ny erfaring for babyene. Noen voksne kan komme hastende til forestillingen stresset over det som hendte rett før. Andre kan komme i god tid og sitte og vente. Noen er kjente i kirkerommet, andre har knapt vært i et slikt rom før. I hvert fall har de fleste ikke sittet på gulvet og i sokkelesten slik som på teaterforestillingene våre. De trenger tydelige beskjeder om hvordan de kan forholde seg til forestillingen, til rommet og til oss ansatte/ skuespillere. Ofte trenger de å bli oppmuntret til å la barna utforske selv. Mange foreldre holder 
barna fast eller henter dem tilbake til fanget underveis i forestillingen. Det gjør at de mest nysgjerrige blir begrenset mer enn de behøver.

\section{Et møte med Lev Vygotskij og Sosiokulturell LERINGSTEORI}

Fem år etter første forestilling begynte jeg å skrive på min mastergradsavhandling i kirkelig undervisning (Oveland 2019). Det var da veldig inspirerende og spennende å få lov til å forske på egen praksis og belyse denne ved hjelp av teori. I møte med dette arbeidet ble jeg bevisst på hvor lite jeg i utdanningsløpet mitt hadde lært om småbarnspedagogikk og barn 0-3 år, og jeg ble overrasket over hvor lite litteratur det fantes å sparre med både innen småbarnspedagogikk, teater og religion. Men Lev Vygotskijs teorier om sosiokulturell læring ga gjenklang for noen av de erfaringene og refleksjonene vi har gjort oss underveis i arbeidet med babyteater i kirken. Vygotskijs teorier bygger på at læring skjer i samhandling med andre, at vi lærer ut ifra hva vi allerede mestrer og kan. Hans teorier sier også noe om at vi kan lære av en «smartere kamerat», en som kan litt mer enn det vi kan. Og slik vokser vi i kunnskap og kjennskap sammen. Vygotskij sier videre at artefakter har en viktig funksjon for læringen vår. Igjen viser han til hvordan vi i sosiale sammenhenger lærer hvordan vi forstår og bruker tingene. Det starter med at vi initieres for noe fysisk og at det fysiske deretter blir et begrep og en forståelse i hodet vårt. (Vygotskij 1978: 57, 84, 85, 88.)

Møtet med Vygotskijs teorier har gitt meg grunnlag for å se at babyteateret er et slikt sosial læringsfellesskap der babyene erfarer og lærer sammen med hverandre, med sine voksne ledsagere og med oss skuespillere. De introduseres for artefakter og erfaringer som de senere vil kunne benytte seg av på nytt for igjen å lære noe.

Trosopplæringsplanen og helhetlig trosopplæringsarbeid Både gjennom praksiserfaring og $i$ lys av litteratur gjorde vi og jeg oss noen refleksjoner rundt tilrettelegging av trosopplæring for de aller minste i kirken og planarbeidet. For det første: scenekunst og musikk er gode redskaper i møte med en tilrettelagt trosopplæring for de minste barna. Samhandling og læring i fellesskap er essensielt. Måten man behandler tid, sted og rom på må være gjennomtenkt. Vi kan være frimodige på bruk av kirkerommet. Samtidig er det viktig å lage et mindre sted i det store rommet der samhandling kan finne sted. Det er viktig å inkludere og informere de voksne ledsagerne og trygge dem på deres rolle. Trosopplæringsplanen bør være bygget opp ved hjelp av byggeklosstankegang. Det betyr at man tidlig i trosopplæringen kan og bør bruke ord, handlinger og gjenstander som man senere vil møte igjen. Ikke fordi man nødvendigvis trenger en spesiell «kloss» eller erfaring for å komme videre, men fordi de indre bildene kommer av et møte med noe ytre. Alle klosser og erfaringer er med 
på læringsprosessen som barna benytter seg av her og nå, og videre i livet.

Gjennom arbeidet med babyteater i kirken har vi sett at det er mulig, og viktig, å gi de aller minste barna et tilbud i kirken i tillegg til de tradisjonelle sangtilbudene. 0-3- årsfasen har nytte av, behov for, og rett på en god og tilrettelagt trosopplæring.

\section{LitTERATUR}

Hovik, Lise. 2014. "De røde skoene - et kunstnerisk og teoretisk forskningsprosjekt om teater for de aller minste». Ph.d. avhandling. NTNU

Oveland, Elin. 2019. oi! Se! Dåpen! Babyteater i trosopploeringen i Den norske kirke: babyteater som loeringsfremmende aktivitet https://hdl.handle.net/11250/2647243

Taube, Gerd, i Schneider, Wolfgang (ed.). 2009. "Theatre for early years: research in performing Arts for children from birth to three». Peter Lang Internationaler Verlag der Wissenschaften

Vygotsky, Lev Semenovic. 1978. "Mind in Society: The Development of Higher Psychological Processes.» Harvard University Press

www.Gudsrikeleiken.no 